\title{
Appointing Australian Judges: A New Model
}

\author{
SIMON EVANS ${ }^{*}$ AND JOHN WILLIAMS ${ }^{\dagger}$
}

\begin{abstract}
The article argues for reform in the process by which members of the Australian judiciary are selected. Such reform is needed in order to ensure two things. First, that the judiciary retains the independence that is essential for it to discharge its constitutional functions. And, second, that it reflects the society from which it is drawn and continues to enjoy the confidence of that society.

We recommend that Australia adopt a process for judicial appointments that is based on the process recently established for England and Wales under the Constitution Reform Act 2005 (UK). Appointments would continue to be made by the executive. Judicial Appointments Commissions (consisting of three judicial members, three legal members and six non-legal members - including the Chair) would recommend to the executive the names of three persons from among whom the appointment must be made. The Commissions' recommendations would be the culmination of an evidence-based process involving applications, references, interviews and in some cases practical assessment of relevant skills.
\end{abstract}

\section{Introduction}

The article argues for a particular set of reforms of the process by which members of the judiciary are selected. In advocating these reforms we do not suggest that the appointment process to date has entirely failed. Measured in historical and international terms the Australian judiciary is acknowledged to be of outstanding quality and has enjoyed the public's confidence. Nonetheless, it should be remembered that the current system is itself a product of reform and adaptation. ${ }^{1}$ Further reforms are now needed in order to ensure two things. First, that the judiciary demonstrably retains the independence and competence that is essential for it to discharge its constitutional functions. And, second, that it reflects the

* Associate Professor and Deputy Dean, Melbourne Law School, University of Melbourne. The research for this paper was supported by the Judicial Conference of Australia. An earlier version of this article was presented at the JCA Colloquium, 7-9 October 2006. This paper does not reflect the views of the JCA. We acknowledge the research assistance of Rayner Thwaites, Anna Hood, Jess Moir, Christopher Tran and Tessa Setiadi, and the valuable comments of Justices Sackville, Debelle, Basten, Hasluck and Chesterman.

$\dagger$ Professor, School of Law, University of Adelaide.

1 For some developments since federation, see, for example, James Crawford \& Brian Opeskin, Australian Courts of Law (4th ed, 2004) at 127; Forge v Australian Securities and Investments Commission (2006) 228 CLR 45. 
society from which it is drawn and continues to enjoy the confidence of that society.

While the collective strength and quality of the Australian judiciary is not in doubt, it is the case that particular appointments have attracted criticism, either in relation to the character and ability of the individual chosen or their conduct while in office. ${ }^{2}$ It is a notorious fact that judicial officers have been appointed, including to the High Court, ${ }^{3}$ whose character and intellectual and legal capacities have been doubted and whose appointments have been identified as instances of political patronage. ${ }^{4}$

A further and persistent general criticism of the appointment process relates to the resulting composition of the various courts. For instance, speaking in 1983, Justice Lionel Murphy noted that ' $[w]$ hen it comes to women judges we have not even reached the stage of tokenism'. ${ }^{5}$ Such criticisms are not limited to the gender composition of the courts. ${ }^{6}$

Australia is not alone in considering reform of the appointments process. ${ }^{7}$ Indeed, similar criticisms of the classic Westminster appointments process have already resulted in review and reform in other parts of the common law world. Those experiences provide the models for the direction that Australia should now take.

The purpose of this article is not to examine in detail the criticisms of the current appointments process or to survey the various appointment processes in Australia and overseas. These tasks have already been undertaken by others. ${ }^{8}$ The purpose of this article is to suggest a viable appointments model within the institutional and political constraints existing in Australia today that addresses the need to ensure an independent and competent judiciary that has the confidence of a diverse society.

2 Enid Campbell \& H P Lee, The Australian Judiciary (2001) at 77, 101-11.

3 See, for example, James Douglas, 'Sir Charles Powers' in Michael White \& Aladin Rahemtula (eds), Queensland Judges on the High Court (2003) at 171.

4 See, for example, Chris Merritt, 'Selection Mystery' 'Prejudice', The Australian (9 March 2007) at 23 (identifying five recent appointments as raising issues of inexperience and political connections).

5 Lionel Murphy, 'Address to the National Press Club' in Tony Maniaty (ed), The Power of Speech (1989) at 97.

6 Commonwealth Attorney-General Michael Lavarch, Discussion Paper: Judicial Appointments - Procedure and Criteria (1993) 6-9 at 16-19; Greta Bird, 'Power, Politics and the Location of "the Other" in Multicultural Australia' in The Criminal Justice System in a Multicultural Society, Australian Institute of Criminology Conference Proceedings, Melbourne, 4-6 May 1993, <http://www.aic.gov.au/conferences/multiculturalism/> accessed 22 September 2006 (copy at $<\mathrm{http}: / /$ www.webcitation.org/5XYnVwD4Q> accessed 9 May 2008); Australian Law Reform Commission, Multiculturalism and the Law, Report No 57 (1992) at 29, 33-4; Elizabeth Handsley, "'The judicial whisper goes around": appointment of judicial officers in Australia' in Kate Malleson \& Peter H Russell (eds), Appointing Judges in an Age of Judicial Power: Critical Perspectives from Around the World (2006) at 122.

7 See generally Kate Malleson \& Peter H Russell (eds), Appointing Judges in an Age of Judicial Power: Critical Perspectives from Around the World (2006).

8 See, for example, ibid. 
The rest of this paper is in three parts. First, we set out the fundamental principles that must guide any set of arrangements for appointment to the Australian judiciary. Secondly, we analyse relevant overseas models that could provide a basis for an Australian appointments system. Thirdly, we argue that a sensitive adaptation of one such model, the UK Judicial Appointments Commission, is the appropriate basis for an Australian system of judicial appointments commissions and is consistent with the guiding principles for any system of appointments.

\section{Guiding Principles}

The model that we develop in Part 4 of this paper tracks four guiding principles. We do not pretend that these principles represent an exhaustive list. Indeed, even within this list there is a degree of overlap. However, they mark out the values that inform the model. This section outlines the four guiding principles and their implications for any judicial appointment process. These principles are matters of constitutional significance: appointments should be made solely on the basis of merit, properly understood; an appointments process should ensure judicial independence; an appointments process should ensure equality of opportunity, and hence diversity, in appointments in the interests of a judiciary that reflects the society from which it is drawn; and an appointments process should include appropriate accountability mechanisms.

\section{A. Merit-Based Appointments}

The first principle is that appointments to the Australian judiciary must be made solely on the basis of merit. As the former Attorney-General Philip Ruddock said, " $\mathrm{t}]$ he Government believes that the essential criterion for appointment to the federal judiciary is merit." ${ }^{9}$ Nothing in this paper is intended to cast the slightest doubt on this foundational principle.

A set of arrangements involving a judicial appointments commission is consistent with appointment on the basis of merit. (The Judicial Appointments Commission in England and Wales (and for the UK Supreme Court) has a mandate to appoint solely on the basis of merit). ${ }^{10}$ However, the concept of merit, which has been said to be an elusive or illusory concept, must be broken down into its constituent elements. As stated by Geoffrey Davies, former Judge of the Queensland Court of Appeal, '[n]o word is more used or abused in this context [the criteria for judicial appointment] than "merit".,11 Without a clear articulation of what constitutes merit, 'the concept becomes almost wholly subjective, allowing

9 Philip Ruddock, 'Selection and Appointment of Judges', (Speech delivered at the University of Sydney, 2 May 2005) at [21].

10 Constitutional Reform Act 2005 (UK) c 4, s 63(2) ('Selection must be solely on merit'). Section $63(2)$ provides that the selecting body must be satisfied that appointees are of good character.

11 Geoffrey Davies, 'Appointment of Judges', (Speech delivered at the QUT Faculty of Law Free Lecture Series, Banco Court, Brisbane, 31 August 2006) <http:/www.law.qut.edu.au/ about/AppointmentofJudges.pdf> 5 accessed 22 September 2006 (copy at $<$ http:// www.webcitation.org/5Xg5ok9jv> accessed 9 May 2008). 
each decision-maker to construct his or her own features which are significant., ${ }^{12}$ The risk is that invocation of merit will simply collapse into the general tendency 'to see merit in those who exhibit the same qualities as themselves', with the result that those who appoint new judges will select those who share the professional, social and gender characteristics of their predecessors. ${ }^{13}$ These concerns are exacerbated by the closed nature of most judicial appointment processes currently used in Australia. ${ }^{14}$

The publication of disaggregated selection criteria provides for greater transparency by allowing candidates to be assessed against a common set of standards, ${ }^{15}$ so enabling 'a more realistic interpretation of what "merit" actually involves for a particular job'. ${ }^{16}$ Disaggregating the components of merit also enables evaluation of the values that are implicit in the concept of merit. ${ }^{17}$ As argued by Justice Sackville, '[t]o the extent that publication of standards encourages public discussion and debate about the qualities required of judicial officers, this might be thought to promote greater public confidence in the judicial appointment process'. 18

The concept of merit in judicial appointments can be disaggregated into subcriteria. The former Federal Attorney-General, for instance, said that ' $[\mathrm{m}] \mathrm{erit}$ means legal excellence, a demonstrated capacity for industry and a temperament suited to the performance of the judicial function'. ${ }^{19}$ That is a starting point. The concept can be further broken down. Commentators ${ }^{20}$ and bodies established to make or recommend judicial appointments in other jurisdictions ${ }^{21}$ have done so. Their lists of sub-criteria encompass legal skills and personal qualities. The legal

12 Sharyn Roach Anleu \& Kathy Mack 'Judicial Appointment and the Skills for Judicial Office' (2005) 15(1) Journal of Judicial Administration 37 at 38.

13 Ruth McColl, 'Women in the Law' (Speech delivered at the Anglo-Australian Society of Law, Court of Appeal, Supreme Court of New South Wales, 3 May 2006) <http:// www.lawlink.nsw.gov.au/lawlink/Supreme_Court/ll_sc.nsf/pages/SCO_mccoll030506> accessed 22 September 2006 (copy at $\langle\mathrm{http} / /$ www.webcitation.org/5XYnlLXDI $>$ accessed 4 May 2008), (quoting the Chief Justice of Canada, Beverley McLachlin PC).

14 Roach Anleu \& Mack, above $\mathrm{n} 12$ at 38.

15 Ronald Sackville, 'Judicial Appointments: A Discussion Paper' (2005) 14(3) Journal of Judicial Administration 117 at 140.

16 Roach Anleu \& Mack, above $n 12$ at 47, quoting Claire Burton, Redefining Merit (1988) at 10.

17 Roach Anleu \& Mack, above $\mathrm{n} 12$ at 47.

18 Sackville, above $\mathrm{n} 15$ at 140 .

19 Ruddock, above $\mathrm{n} 9$ at [22].

20 Lavarch, above $n 6$ at [2.2.1]-[2.13.4]; Sir Anthony Mason 'The Appointment and Removal of Judges' in Judicial Commission of New South Wales, A Fragile Bastion: Judicial Independence in the Nineties and Beyond (1997) at 10-11. See also Law Council of Australia, Policy on the Process of Judicial Appointments (2000) <http://www.lawcouncil.asn.au/get/policies/ 1957352833/0.pdf $>$ accessed 22 September 2006 (copy at $<$ http://www.webcitation.org/5XY nooqLH $>$ accessed 9 May 2008).

21 Department of Constitutional Affairs, 'Competency Frameworks' in Judicial Appointments in England and Wales: Policies and Procedures (2005) <http://www.dea.gov.uk/judicial/ appointments/jappinfr.htm> accessed 22 September 2006 (copy at $<\mathrm{http}: / /$ www.webcitation.org/5Xg1nuyn1> accessed 9 May 2008); Department of Constitutional Affairs, 'Changes from 3 April 2006' in Judicial Appointments in England and Wales: Policies and Procedures <http://www.dca.gov.uk/judicial/process.htm\#3rdaprilchanges〉 accessed 22 September 2006 (copy at <http://www.webcitation.org/5Xg236fKq > accessed 9 May 2008). 
skills relate to knowledge of the law, intellectual capacity and experience; the capacity to 'stage manage' proceedings in the courtroom; facility with complex fact situations and arguments; and the ability to write judgments. The personal qualities listed include integrity, impartiality, industry, a strong sense of fairness, decisiveness, understanding and a sound temperament. ${ }^{22}$ Certain other desirable skills may differ between courts. For example, forensic experience may be highly valuable for appointment to a criminal trial court but less important for appointment to an appellate court; equally, the intellectual skills required for appointment to an appellate court may be of less significance in evaluating candidates for appointment to high volume jurisdictions. One further implication of disaggregating merit in this way is to recognise that there is no necessary correlation between successful practice at the bar and the skills required for judicial office. ${ }^{23}$

Appointments should be made on the basis of evidence demonstrating that the appointee possesses the various qualities that together constitute merit. No other process is capable of providing reasonable assurance that the appointee is among the most qualified candidates for the position. Without an evidence-based approach, there is too great a risk of subjectivity re-entering the process, despite the attempts to limit it by breaking 'merit' down into its constituent elements.

If the concept of merit is disaggregated and clearly articulated and applied on the basis of evidence, it is consistent with the best of existing practice in judicial appointments. Further, disaggregating the concept highlights the shortcomings of existing processes that fail to identify worthy candidates beyond the range of the 'usual suspects'. As Roach Anleu and Mack have observed, there is no reason to think that merit resides predominantly in the narrow group that has historically dominated the Australian judiciary. ${ }^{24}$

\section{B. Judicial Independence}

The independence of the judiciary is a fundamental principle of Australian constitutionalism that must inform any judicial appointment process. However, it does not, even within the tradition of Australian constitutionalism, demand an absolute separation of all aspects of the judicial process from the political process. Indeed, such an absolute separation is not possible under the Constitution. ${ }^{25}$ Moreover, it is perhaps not desirable that appointments be wholly independent from politics. Ultimately, appointment, remuneration and removal are within the constitutional competence of the executive and the parliament. Comment on, and criticism of, the judiciary remain legitimate for members of the executive and the parliament. Indeed, any reform of judicial appointment processes will require debate in, and action from, the political branches.

22 See Sackville, above $\mathrm{n} 15$ at 129 (referring to the selection criteria adopted by the Tasmanian Department of Justice), 133 (summarising the criteria for judicial appointment in England and Wales).

23 Id at 139

24 Roach Anleu \& Mack, above $\mathrm{n} 12$ at 39

25 Which requires that federal judges be appointed by the Governor-General on the advice of Ministers. 
What is essential is that decisional independence be guaranteed to judicial officers. The core of judicial independence is freedom from influence in the central judicial task of adjudicating disputes about legal rights that arise between private parties, between the State and private parties, and (in a federation) between components of the State. The core is protected through institutional arrangements such as tenure, remuneration and the jurisdictional separation of powers. ${ }^{26}$ As we have already noted, it is inescapable that politics will have a role to play in the appointment process. However, if appointments are perceived to be made on the basis of political patronage there is a threat to (at least the appearance of) decisional independence. It is impossible - and undesirable - to remove the political entirely from the appointments process. Indeed, in our view, 'political' considerations, in the sense of responsibility and accountability for appointments, need to be intensified rather than obscured. What an appointments model should attempt to do is attenuate the direct influence of the political branch on the appointment process and subject its involvement in the appointment process to greater transparency and accountability, while preserving all the existing constitutional arrangements for ensuring decisional independence.

\section{Diversity}

Judges are not representatives of any group or constituency. Their duty is to 'do right to all manner of people according to law without fear or favour, affection or ill-will'. ${ }^{27}$ Equally, the judiciary as a whole does not need to be representative of any group or constituency.

However, a judiciary — indeed any institution — that fails to reflect the makeup of the society from which it is drawn will sooner or later lose the confidence of that society. ${ }^{28}$ As Justice McHugh put it, "when a court is socially and culturally homogeneous, it is less likely to command public confidence in the impartiality of the institution'. 29 The Australian judiciary is such an institution. The Australian judiciary as currently constituted does not reflect Australian society. To focus just on gender: in 2006, there were ' 26 female judges of the State Supreme Courts, including two appellate Judges, one President of the Court of Appeal and one Chief Justice, namely Chief Justice Marilyn Warren of the Victorian Supreme Court. At the Federal level, there [were] 6 female judges of the Federal Court and 17 female judges of the Family Court, which is led by Chief Justice Diana Bryant'. This amounts to an approximate $20 \%$ representation on the bench of the superior courts. $^{30}$

26 Grollo v Palmer (1995) 184 CLR 348 at 376-77; Kable v Director of Public Prosecutions (NSW) (1996) 189 CLR 51 at 82.

27 High Court of Australia Act 1979 (Cth) s 11, sched.

28 Department of Constitutional Affairs, Constitutional Reform: A New Way of Appointing Judges (2003) at 3, 19-20. See also The Commission for Judicial Appointments, Annual Report 2002 at [8.3] and Mason, above n20 at 7.

29 Michael McHugh, 'Women Justices for the High Court' (Speech delivered at the High Court dinner hosted by the West Australian Law Society, 27 October 2004) <http:// www.hcourt.gov.au/speeches/mchughj/mchughj_27oct04.html> accessed 11 September 2006 (copy at $<\mathrm{http}: / /$ www.webcitation.org/5Xg2Ccy9D $>$ accessed 9 May 2008). 
The point is not that the present system results in the appointment of people who do not have the required qualities for judicial office. Rather, the current process systematically overlooks others who do have the required qualities. ${ }^{31} \mathrm{~A}$ range of considerations support the argument that a judiciary should reflect the society of which it is part. Here we follow a summary of these considerations presented by Alan Paterson in his study of the Scottish appointments system. ${ }^{32}$

- First, there should be no place in the appointments process for direct or indirect discrimination on unacceptable grounds. The current system that relies on soundings and a network of contacts in conjunction with an unarticulated concept of merit is open to (at least perceptions of) such influences. 33

- Second, this perception is to the detriment of public confidence in the courts.

- Third, a judiciary that reflects the society from which it is drawn 'represents a sound use of human resources ... modern societies cannot afford to lose the intellectual power and energy of ... [so much of their] ... population' ${ }^{34}$ As Baroness Prashar, Chair of the Judicial Appointments Commission in the UK, recently said, " $\mathrm{t}$ ] he benefit of widening the range of applicants has a powerful simplicity. If more, well-qualified people apply to be judges, the merit of those selected will either remain the same as now or be enhanced. And if the appointments process excludes consideration of irrelevant factors then we might also expect appointed judges to come from a very wide range of backgrounds'. 35

- Fourth, judges from diverse backgrounds may serve as role models for wider community involvement in the legal profession.

30 Terence Higgins, 'Women in Law: Past Achievements and Future Directions' (Speech delivered at the Sir Richard Blackburn Lecture, Pilgrim House, Canberra, 16 May 2006), <http:// www.courts.act.gov.au/supreme/content/pdfs/Blackburn\%20Lecture\%202006.pdf $>$ accessed 23 April 2008 at 7-8 (copy at $<$ http://www.webcitation.org/5Xg2NtnSw $>$ accessed 9 May 2008).

31 Annual Report 2002, above $\mathrm{n} 28$ at [8.3].

32 Alan Paterson, 'The Scottish Judicial Appointments Board: New Wine in Old Bottles?' in Kate Malleson \& Peter H Russell (eds), Appointing Judges in an Age of Judicial Power: Critical Perspectives from Around the World (2006) 13 at 26-31. We place no weight on what Paterson identifies as the third consideration in his survey - that a wider range of appointments would change and perhaps improve judicial decision-making. As Paterson's survey demonstrates, opinions are widely divided on the evidence for this consideration: at 29-31. See also Cheryl Thomas, The Commission for Judicial Appointments, Judicial Diversity in the United Kingdom and Other Jurisdictions: A Review of Research, Policies and Practices (2005) at 57-60<http:/ /www.cja.gov.uk/fïles/Judicial_Diversity_Review_Report_PDF.pdf> aceessed 11 September 2006 (archived <http://web.archive.org/web/*/http://www.cja.gov.uk/files/Judicial_Diversity_ Review_Report_PDF.pdf $>$ accessed 9 May 2008).

33 Paterson, above $\mathrm{n} 32$ at 26.

34 Beverley McLachlin, 'Promoting Gender Equality in the Judiciary', Seminar to the Association of Women Barristers, House of Commons (Canada) (2 July 2003) at 6, quoted in Paterson, above $n 32$ at 31 .

35 Baroness Usha Prashar, 'Speech at the Annual ILEX Luncheon' (Clothworkers' Hall, London, 17 May 2006) at [10]. 


\section{Accountability through Transparency}

A basic premise in a Westminster system is responsible government, which has been supported and supplemented through other institutional arrangements such as parliamentary and statutory bodies. Parliamentary committees and the rise of the 'new administrative law' arrangements are examples of a modern and more robust institutional system of executive accountability. Outside the parliament, the media and civil society organisations regularly scrutinise the exercise of public power, complementing the formal institutional accountability mechanisms.

Accountability for the exercise of executive power is an aspect of a wider and pervasive principle of modern liberal constitutionalism that demands accountability for the exercise of public power in general. As a branch of government wielding public power, the judiciary is subject to this principle. Obviously the judiciary is accountable for its decisions through the right to open justice, an appellate procedure and an increasing willingness to engage in public discussion as to its role. The last of these has been the result of a changed understanding of the traditional function of the Attorney-General, particularly at the federal level. ${ }^{36}$

The question that arises here is how best to ensure executive accountability in the appointment process. First, it is important to recognise the limitations of the current accountability measures. As a means of holding the government to account for its appointees, the current system is both unfocused and lacks rigour. Moreover, the accountability of the government to the parliament is retrospective. Good public administration is founded upon the establishment of transparent processes and standards in advance of their operation and application. The current absence of formal and articulated processes and standards for judicial appointments leads to disingenuous statements by Attorneys-General when announcing an appointment. They are forced to make the generally implausible comment that ' $\mathrm{X}$ was the outstanding candidate'. Such statements overlook the wealth of talent available and further reinforce the idea that appointment can be based on personal, professional and perhaps political connections to the AttorneyGeneral.

This does not mean that political accountability for appointments is unimportant or that responsibility for appointments should be removed completely from the executive government. The involvement of the political branch in appointments may open up the possibility of appointing some candidates whom a thoroughly depoliticised appointments process would avoid. James Allan has argued:

[Under systems of direct appointment by the executive government] someone and some political party can be held politically accountable for the selection. There is simply more openness and accountability (for choosing, say, another male or a former politician). Plus, a decision to opt for a less activist type of judge or for someone with unorthodox views on the proper way to interpret constitutional

36 Daryl Williams, 'The Role of the Attorney-General' (2002) 13 Public Law Review 252 at 26162. 
provisions can be deliberately and consciously taken. The government and its attorney-general will have to live with the political ramifications of such a decision, true, but I see no reason why such options should be foreclosed (or made extremely difficult, as surely they would be with an indirect process) in these days of highly powerful judiciaries. ${ }^{37}$

In Allan's view, an indirect appointments system blunts the political opposition: '[q]uite simply, it is easier to attack the constitutional improprieties of an attorneygeneral than it is to mount a case against a Judicial Appointments Board, all of whose members appear thoroughly apolitical, legally qualified, and nice'. ${ }^{38}$ Allan's argument is overdrawn and focuses too narrowly on one dimension of the appointments process. But it is valuable in highlighting the role of political accountability that would be lost in a move to a model under which the AttorneyGeneral had no role to play in appointments.

The limitations of the current mechanisms for holding governments accountable for judicial appointments do not mean that the entire modern administrative law system should be directed at judicial appointments. Judicial and administrative review of appointment decisions is plainly inappropriate. ${ }^{39}$ Rather, political accountability should be supplemented with accountability mechanisms that are appropriate to the nature of this kind of exercise. Transparency is a key means to provide greater accountability in the appointment process. ${ }^{40}$ In other areas of public administration, parliamentary and statutory measures of accountability are present. By contrast, the current process has minimum transparency, for example, only requiring the Commonwealth Attorney-General 'to consult with the Attorneys-General of the States' in relation to High Court appointments. There is no external scrutiny of the current selection processes, which feeds distrust, perhaps misplaced, that selection is made upon a basis other than the merit of the candidate. In short, where transparency can be accommodated consistently with other important interests, including confidentiality, it should be accommodated. This extends to the process and criteria for appointment and the identity of those making recommendations about appointment. ${ }^{41}$

While our model calls for greater transparency and thus accountability in the selection process, transparency is not an overriding principle. There are powerful

37 James Allan, Judicial Appointments in New Zealand: If it were done when 'tis done, then 'twere well it were done openly and directly' in Kate Malleson \& Peter H Russell (eds), Appointing Judges in an Age of Judicial Power: Critical Perspectives from Around the World (2006) 103 at 115.

38 Id at 116

39 See, for example, Administrative Review Council, What Decisions Should be Subject to Merits Review? (1999) at 20-22 (factors that may exclude merits review: decisions to appoint a person to undertake a specified function, recommendations to ultimate decision-makers, decisions where there is no appropriate remedy); Administrative Review Council, The Scope of Judicial Review (2006) at 57-58 (in most cases, limits on judicial review are justified for decisions where there is neither a right to a benefit nor a duty on the decision maker to consider conferring a benefit; sometimes, limits on judicial review are justified for decisions where there is a particular need for certainty or decisions about policy).

40 Some measure of retrospective accountability is also appropriate. We discuss this below. 
institutional and pragmatic reasons for preserving strict confidentiality of aspects of the process. For example, if names of potential appointees, especially in small jurisdictions, were made public it may adversely affect relationships with clients. The upshot may be to discourage meritorious individuals from seeking appointment. Even in larger jurisdictions, breaches of confidentiality would undermine the operation of the system. This is not special pleading for judicial appointments. Confidentiality is a common feature of appointments processes generally. It ensures that meritorious candidates are not deterred by the prospect of disclosure of a candidacy that might be perceived as overreaching or that might (wrongly) be perceived as reflecting badly on the candidate if it was ultimately unsuccessful. Equally, confidentiality of references ensures that referees are not deterred from being fully candid about the evidence that supports (or undermines) the candidate's application.

\section{E. Context and Constraints}

These four guiding principles are important. But so too are the constitutional context and practical constraints. Any model for judicial appointments must take into account the federal structure and the separation of powers. The model must also acknowledge a degree of asymmetry between the Commonwealth, State and Territory systems.

First, at the Commonwealth level, the guarantees and limitation derived from Chapter III of the Constitution must be observed. While we believe the involvement of, say, the Chief Justice of the Federal Court as a member of a federal appointments commission is not incompatible with the judicial function (provided that he or she consents to his or her involvement) ${ }^{42}$ there are limits upon the functions of any proposed judicial appointments commission. For instance, a federal appointments commission would be a recommending body, not an appointing body. Thus any recommendations must be transmitted to the GovernorGeneral through the Federal Executive Council. ${ }^{43}$ This maintains the current system of ministerial accountability for appointments.

41 Critics of appointments commissions also highlight the value of transparency. F L Morton recently argued that, as power cannot be depoliticised (a point with which we agree), ' $[t]$ he best one can do is to make the exercise of power as transparent as possible, and then create effective checks and balances': Frederick Morton, 'Judicial Appointments in Post-Charter Canada: A System in Transition' in Kate Malleson \& Peter H Russell (eds), Appointing Judges in an Age of Judicial Power: Critical Perspectives from Around the World (2006) 56 at 75. He agrees with James Allan that the best achievable system would be one in which 'the judges of the highest courts are appointed "'openly and directly by the elected government of the day", with opportunity for opposition parties to question appointees (not, it seems, prospective appointees) on their legal and constitutional outlook: ibid. He concludes: 'The government will still get the judge it wants, but it can be held accountable for - or get credit for - its appointments at the next election': ibid. Plainly, Morton's concern is with the highest courts, particularly those exercising powers of judicial review on substantive rights issues. But even in relation to these courts his proposal is for a very diffuse form of accountability that (in Australia, at least) would lead to a novel overt politicisation of the courts.

42 Wilsonv Minister for Aboriginal and Torres Strait Islander Affairs (1996) 189 CLR 1 at 13, 41.

43 Commonwealth Constitution $\mathrm{s} 72$. 
Second, the situation for the States, while not as constitutionally as rigid as the Commonwealth, still suggests caution in radical departure from the current processes. Thus while there is no strict separation of powers at the State level, ${ }^{44}$ there is merit in limiting the function of the appointments commission to recommendations.

Third, there are a number of practical considerations applicable at both levels. Should there for instance, be separate appointment bodies for the local or magistrates courts and one for senior courts? Alternatively, should each State have a separate appointments commission, or should there be a single national appointments commission? The likely workload of the appointments body, given the size of the jurisdiction or jurisdictions involved and the existing workloads of the likely members of the appointments body, will constrain the approach taken. A judicial appointments commission such as we suggest below will inevitably demand more human and material resources than the current political arrangements for judicial appointments. The arrangements must be flexible enough to apply to all judiciaries, and any benefits gained must justify the outlay in additional resources. One example of logistical considerations emerges from the experience in England and Wales. The Commission for Judicial Appointments concluded that the traditional automatic consultations of many sources were 'wasteful of judicial time'. They advocated better targeted and solicited input 'focused on giving better quality responses to those candidates and about those issues where third party evidence is likely to be helpful ... The views of senior judges on candidates, of whom they have knowledge and experience, need to be captured in a more balanced and accountable way'. ${ }^{45}$ Any model must be attentive to concerns of this kind.

\section{Relevant Overseas Models}

Many comparable common law jurisdictions have moved to reform their appointments processes in response to concerns similar to those expressed in Australia. Some processes are clearly inappropriate for Australia: neither the system of elected judges (under which approximately $90 \%$ of United States State judges are chosen) nor the system of partisan scrutiny by a Senate Committee (as a preliminary to the United States Senate's consent to federal judicial appointments) is appropriate for Australia. Each system is highly transparent but infects the appointment process with a partisan flavour that is alien to Australia's constitutional traditions.

Equally the South African model is inappropriate. The process centres on the constitutionally-established Judicial Services Commission, which includes five legal professionals, three judges, 11 politicians and four other politically selected

44 Kable v Director of Public Prosecutions (NSW) (1996) 189 CLR 51 at 77-8; Forge v Australian Securities and Investments Commission (2006) 228 CLR 45 at 65-6.

45 Commission for Judicial Appointments, The Commissioners' Review of the High Court 2005 Competition: Report to the Lord Chancellor (2006) [2.13]. See also the comments on judicial input in Chapter 6. 
members. The political representation and the openness of the process (the JSC publishes transcripts of interviews it holds with judicial candidates) would be problematic and unnecessary to adopt in Australia, especially in the smaller jurisdictions.

New Zealand's modifications of the traditional executive-centred appointments process have been minor. Appointments are still made by the Governor-General, acting on the advice of the Attorney-General (or, in the case of the Chief Justice, on the advice of the Prime Minister). ${ }^{46}$ The process is still regulated by convention rather than law. One such convention appears to be that judges are selected according to four 'clearly defined, transparent and publicly announced criteria': legal ability; qualities of character; personal technical skills; and reflection of society. ${ }^{47}$ The Attorney-General also mentions appointments at Cabinet after they have been decided - convention suggests that Cabinet is not supposed to have any input into these decisions. ${ }^{48}$ One may legitimately doubt whether these conventions tie the hands of the executive in any meaningful way, as the controversy over the appointment of the initial complement of judges to the Supreme Court suggests. ${ }^{49}$

In Canada, since 1988, candidates for appointment to provincial superior courts have had to submit formal applications, be scrutinised by the Federal Commissioner of Judicial Affairs and be interviewed by provincial or territorial committees. ${ }^{50}$ More recently, the executive's discretion in relation to Supreme Court appointments has been the subject of intense debate and has been somewhat curtailed. ${ }^{51}$ After an interim process that applied to two appointments in $2004,{ }^{52}$ a new process was adopted in 2005 but was interrupted by the Liberal Party's loss at the general election. In accordance with a policy statement issued by the government early in $2005,{ }^{53}$ an ad hoc advisory committee was established to

46 See Judicature Act 1908 (NZ) ss 4(2) and 57(2) and Supreme Court Act 2003 (NZ) s 17. There are a few exceptions to this statement. Allan, above n37 at fn5.

47 Ministry of Justice, Judicial Appointments: Office of the High Court Judge (2003) <http:// www.justice.govt.nz/pubs/other/pamphlets/2003/judicial-appointments/high-courtjudge.html \#Criteria\%20for\%20appointment> accessed 14 September 2006 (copy at $<$ http:// www.webcitation.org/5Xg32G4p7> accessed 9 May 2008).

48 Judicial Appointments, Courts of New Zealand <http:/www.courtsofnz.govt.nz/about/judges/ appointments.html $>$ accessed 14 September 2006 (copy at $<$ http://www.webcitation.org/ $5 \mathrm{Xg} 3 \mathrm{FMZXO}>$ accessed 9 May 2008).

49 Allan, above $\mathrm{n} 37$ at 115.

50 Morton, above $n 41$ at $67-68$.

51 See, for example, Minister of Justice (Canada), Proposal to Reform the Supreme Court of Canada Appointments Process (April 2005) <http://canada.justice.gc.ca/eng/dept-min/pub/scccsc/scc-csc.pdf $>$ accessed 14 September 2006 (copy at $<\mathrm{http} / /$ www.webcitation.org/ $5 \mathrm{XhtKbB} 4 \mathrm{H}>$ accessed 9 May 2008).

52 See Department of Justice (Canada), Report Of The Interim Ad Hoc Committee On The Appointment Of Supreme Court Judges (August 2004) <http://canada.justice.gc.ca/eng/dept$\mathrm{min} / \mathrm{pub} / \mathrm{scj} 2$-jcs2/annexa.html $>$ accessed 14 September 2006 (copy at $<\mathrm{http}: / /$ www.webcitation.org $/ 5 \mathrm{Xg} 3 \mathrm{rlPdH}>$ accessed 9 May 2008).

53 Minister of Justice (Canada), above n51. 
consider evidence of the qualifications of members of a long-list of nominees already identified by the government. The advisory committee consisted of a Member of Parliament from each recognised party, a retired judge, a nominee of the provincial Attorneys-General, a nominee of the law societies and two prominent non-legal Canadians, each of whom come from the region where the vacancy arose. Nominees did not appear before the Committee. The Committee recommended to the Minister three candidates (without ranking them). The government could appoint one of these, or in exceptional circumstances, another person. Although the election intervened before any appointment was made, the new government retained the Committee's list of candidates and made an appointment from that list. However, instead of the Minister then appearing before a parliamentary committee 'to explain the appointment process and the professional and personal qualities of the appointee', the appointee himself (now Justice Rothstein) appeared before the parliamentary committee. In Professor Peter Hogg's words, the Committee's role was to satisfy itself 'that this person has the right stuff to be a judge of the Supreme Court of Canada' 54 This interview process was broadcast live on Canadian television. ${ }^{55}$ While this model may be appropriate for Canada's highest court, which has a thoroughly politicised role under the Charter and in Canadian federalism, it is inappropriate as a model for Australia's very different courts.

The most likely model for Australia is the model recently implemented in England and Wales under the Constitution Reform Act 2005 (UK). In April 2006, responsibility for identifying judges to be appointed was transferred from the Lord Chancellor, with the Commission for Judicial Appointments fulfilling an oversight role, to the Judicial Appointments Commission ('JAC'). ${ }^{56}$

The JAC is composed of six lay persons, five judges, one solicitor, one barrister, one magistrate and one tribunal member. ${ }^{57}$ Three of the judicial members are selected by the Judges' Council; the Chair and the other 11 members of the Commission by a selection panel. ${ }^{58}$ The Chair of the Commission must be

54 Peter Hogg, 'Judicial Interview Process. Opening Remarks to Ad Hoc Committee on Supreme Court Appointment' (Speech delivered at the Ad Hoc Committee on Supreme Court Appointment', Canada, 27 February 2006) $<\mathrm{http} / /$ www.justice.gc.ca/eng/dept-min/pub/sccesc/sp-dis.html $>$ accessed 6 April 2008. (copy at $<\mathrm{http} / /$ www.webcitation.org/5Xg3w8b3S $>$ accessed at 9 May 2008).

55 Ibid.

56 The process is somewhat different for heads of division, the Court of Appeal and the Supreme Court.

57 Constitutional Reform Act 2005 (UK) c 4, sched 12.

58 The Chair of the appointing panel (who cannot be a practising lawyer or judge, a Commissioner or an MP) is appointed by agreement of the Lord Chancellor and Lord Chief Justice; the remaining members are the Lord Chief Justice, the Chair of the Judicial Appointments Commission (if he or she has been appointed) and a person nominated by the Chair of the appointing panel. See Constitutional Reform Act 2005 (UK) c 4, sched 12. The panel must consider the views of the Bar and Law Society in selecting the professional members of the Commission. 
a lay person ${ }^{59}$ and no Member of Parliament can be appointed to the Commission. The remit of the JAC is to make a recommendation to the Secretary of State for Constitutional Affairs as to who should hold judicial offices for courts below the Court of Appeal. ${ }^{60}$

The Constitutional Reform Act 2005 (UK) sets out clear principles on which the Commission's recommendations must be premised. It explicitly states that selections be founded solely on merit and that the person selected be of good character. ${ }^{61}$ Additionally, the Act mandates that the Commission 'have regard to the need to encourage diversity in the range of persons available for selection for appointments. ${ }^{62}$ In order to help achieve diversity, the Lord Chancellor is permitted to issue guidance about selection procedures for identifying and assessing candidates. ${ }^{63}$ However, the Lord Chancellor must consult the Lord Chief Justice and that each House of Parliament must approve the proposed guidance prior to it being adopted by the Commission. ${ }^{64}$

Beyond these broad guiding principles, the Act leaves it to the Commission to determine the precise selection process to be undertaken. ${ }^{65}$ Since its inception the JAC has been working to formulate a selection procedure that accords with the principles articulated in the Act. To date, it has specified five core qualities and abilities generally required of a candidate for any judicial post ${ }^{66}$ as well as publishing guidance on what constitutes 'good character'. ${ }^{67}$ It has also devised mechanisms to 'encourage a wide range of applicants' to apply and to minimise barriers individuals face to becoming part of the judiciary. ${ }^{68}$ The Commission has determined to broaden the range of applicants by employing the media and professional organisations to raise awareness of appointment opportunities through print and online, and by developing targeted advertising campaigns for each judicial position that becomes available. ${ }^{69}$ A novel approach has been the use of 'roadshows', which provide potential candidates with information on the

59 Constitutional Reform Act 2005 (UK) c 4, sched 12.

60 See generally the Judicial Appointments Commission's website, <www.judicialappointments. gov.uk> aceessed 9 May 2008.

61 Constitutional Reform Act 2005 (UK) c 4, s 63(2)-(3).

62 Constitutional Reform Act 2005 (UK) c 4, s 64(1).

63 Constitutional Reform Act 2005 (UK) c 4, s 65(1).

64 Constitutional Reform Act 2005 (UK) c 4, s 66(1).

65 See for example, Constitutional Reform Act 2005 (UK) c 4, s 70(2).

66 Judicial Appointments Commission <http://www.judicialappointments.gov.uk/select/ qualities.htm> accessed 5 April 2008 (copy at $<\mathrm{http}: / / \mathrm{www}$.webcitation.org/5Xg4Bm00p $>$ accessed 9 May 2008).

67 Good character being a statutory requirement for selection: see Constitutional Reform Act 2005 (UK) c 4, s 63(3). The guidance was published at the end of 2007: see Judicial Appointments Commission<http://www.judicialappointments.gov.uk/docs/Judicial_Appointments_Commission_ Good_Character_Guidance.pdf $>$ accessed 5 April 2008 (copy at $<$ http://www. webcitation.org/ $5 \mathrm{Xg} 4 \mathrm{IQWjv}>$ accessed 9 May 2008).

68 Baroness Usha Prashar, above n35.

69 Ibid; see also Judicial Appointments Commission <http://www.judicialappointments.gov.uk/ select/step.htm> accessed 5 April 2008 (copy at <http://www.webcitation.org/5Xg4QZTQ6> accessed 9 May 2008). 
selection process and first-hand accounts of judicial office. The Commission has also committed itself to collecting data on candidate diversity at each stage of the selection process for the purposes of publication. ${ }^{70}$

Under the current appointments processes, candidates complete an application form and nominate referees, although the Commission may also consult predetermined 'Commission referees' 71 These would probably be senior judges and practitioners, as was the case during the interim appointments processes. The next stage involves a sifting process. Candidates are shortlisted on the basis of their application form and references, or, where they have been utilised, on qualifying tests. The next stage will then vary depending on the nature of the post to be filled. Candidates may need to attend a selection day where they partake in role plays and a panel interview, or otherwise only a panel interview is conducted. The Lord Chief Justice and another person who has previously held the office for which selection is to be made or who has other relevant experience are sent a report on the candidate for their input. ${ }^{72}$ Once this process has been completed the Commission must select one candidate whom it recommends to the Lord Chancellor. ${ }^{73}$ It is then the responsibility of the Lord Chancellor to accept or reject the Commission's recommendation.

If an applicant has a complaint about maladministration by the Commission or the Lord Chancellor during the selection process he or she is entitled to complain directly to the body with which he or she has the complaint or to the Judicial Appointments and Conduct Ombudsman. The Ombudsman is responsible for evaluating all such complaints and determining whether or not it is necessary to investigate them. If it is determined that an investigation is necessary the Ombudsman must investigate the complaint and then issue a report on any action that is required. ${ }^{74}$

\section{A Model for Australian Judicial Appointments}

The model that we propose for Australia in this article is a modified version of the system currently operating in the England and Wales. We do so for the following reasons. 75

First, the model is a cautious and incremental development that does not break with Australia's legal traditions.

Second, a judicial appointments commission provides a workable model that best meets the principles outlined in the first part of the paper. The Commission on

70 See Judicial Appointments Commission <http:/www.judicialappointments.gov.uk/select/ widening.htm $>$ at 5 April 2008 (copy at $<\mathrm{http}: /$ www.webcitation.org/5Xg4fgjFR $>$ accessed 9 May 2008).

71 The selection process is outlined on the JAC's website: see Judicial Appointments Commission $<\mathrm{http}$ //www.judicialappointments.gov.uk/select/step.htm> accessed 5 April 2008 (copy at $<$ http://www.webcitation.org/5Xg52crKo > accessed at 9 May 2008).

72 This is a statutory requirement: see Constitutional Reform Act 2005 (UK) c 4, ss 88(3), 94(3)

73 Constitutional Reform Act 2005 (UK) c 4, s 96.

74 Constitutional Reform Act 2005 (UK) c 4, ss 99-102. 
Judicial Appointments, the predecessor to the UK Judicial Appointments Commission, operated from 2001. There is now a body of work reporting on its operation, its strengths and perceived weaknesses, which confirms the suitability, measured against the principles outlined earlier, of a judicial appointments commission.

Third, the model in operation in the United Kingdom arguably represents best practices within the common law constitutional tradition. As Kate Malleson concludes when examining the recent United Kingdom developments:

Far from being a grab for power on the part of the government, as some commentators initially feared, the proposal for establishing a judicial appointments commission is a rare and commendable example of the executive giving away a source of political control and potential patronage. The creation of

75 The system operating in Scotland is assessed in Paterson, above n32. A somewhat different system operates in Northern Ireland: see Sackville, above n15 at 136. We are not the first to propose a judicial appointments commission for Australia. Other proposals include:

- The Hon Geoffrey Davies recently proposed a Queensland commission consisting of seven members, 'the Chief Justice; either another Supreme Court judge appointed by the Chief Justice or, if the appointment is to the District Court, the Chief Judge of that Court; the President of the Bar; the President of the Law Society; the head of a church in Queensland (to be rotated annually among the various churches); the editor of The Courier Mail or The Australian, to be rotated annually; the local President of Zonta': Davies, above n11. (Zonta is 'a global service organization of executives and professionals working together to advance the status of women worldwide through service and advocacy': Zonta International $<$ http://www.zonta.org $>$ accessed 26 September 2006.)

- Sir Anthony Mason recommended a commission of "not more than nine members of whom at least five should be judges and practising lawyers', perhaps 'two judges, a nominee of the relevant Bar Association, a nominee of the relevant Law Council or Society and a nominee of the Council of Law Deans, one or two nominees of government and two lay persons who should be selected having regard to their capacity to represent the community': Mason, above $\mathrm{n} 20$ at $10-11$.

- Sir Garfield Barwick suggested that there be some restraint on the executive in judicial appointments, including possibly a judicial appointments commission (including 'judges, practising lawyers, academic lawyers, and, indeed, laymen likely to be knowledgeable in the achievements of possible appointees'): Sir Garfield Barwick, 'The State of the Australian Judicature' (1977) 51 Australian Law Journal 480 at 494.

- The Attorney General's Discussion Paper: Judicial Appointments Procedure and Criteria: Attorney General Discussion Paper (1993) at 24-26 summarises the composition of then existing and recommended appointments commissions in comparable jurisdictions (which include judges, practising and academic lawyers, community representatives, AttorneysGeneral, retired judges and politicians, serving politicians and media representatives).

- George Winterton's 1987 proposal differed from ours in insisting that the legal members not be representatives of their professional bodies 'so that they represent nothing but the public interest': George Winterton, 'Appointment of Federal Judges in Australia' (1987) 16 Melbourne University Law Review 185 at 210-11.

For general discussion and more general proposals, see also Sir Gerard Brennan, 'The Selection of Judges for Commonwealth Courts' (2008) 48 Papers on Parliament 1; Amber Augustin, 'Federalism and the High Court: Fixing the appointment process' (2006) IPA Review 22; Sackville, above n15 at142-43; Handsley, above n6 at 136-37; George Williams \& Rachel Davis, 'Reform of the Judicial Appointments Process: Gender and the Bench of the High Court of Australia' (2003) 27 Melbourne University Law Review 819 at 859-863. 
a commission has the potential to secure the long-term independence of the judicial system, to promote the diversification of the bench, and to enhance public confidence in the system. The record of commissions in other jurisdictions in achieving these goals is generally good, although success is not inevitable. The model of commission set up in England and Wales is sufficiently wellconstructed to form the basis for a successful new system. ${ }^{76}$

While our model is informed by the English experience it is not a carbon copy of it. There are significant reasons for departing from some of its details while maintaining its fundamental structure. Opponents of a judicial appointments commission have made the point that there is a huge difference between the number of judicial and quasi-judicial appointments made in the United Kingdom and Australia. ${ }^{77}$ The English Commission is responsible for appointing more than 30,000 officers including tribunal members and lay Magistrates. ${ }^{78}$ Constitutional limitations in Australia prevent widespread use of acting judges and recorders that provide important training ground for English appointments. ${ }^{79}$ Thus, it is argued, there is no need for a judicial appointments commission in Australia. This is a pragmatic argument which misses the point of reform. It is not to reduce the workload of the Attorney-General's department, but to bring a principle-based approach to judicial appointments. Indeed, even if there were only one appointment to be made by the Commonwealth or State and Territory governments this would not detract from the objectives and processes that the model seeks to enshrine.

This article next outlines some of the specific features of the proposed Australian model. It does not profess to prescribe the finer details of the operation of each Australian judicial appointments commission. ${ }^{80}$ Many of those issues rightly should be left to the Commission to determine for itself in light of the general guidelines. What this model does is canvass many of the significant issues in accordance with the general principles previously outlined.

Under our proposal each Commission would:

- Define subsidiary selection criteria tailored to the specific needs of each court that give effect to the primary statutory criterion that judicial appointments are made on merit.

- When notified by the Attorney-General that the government wishes to make an appointment to a particular court, advertise and conduct outreach

76 Kate Malleson, 'The New Judicial Appointments Commission in England and Wales: New Wine in New Bottles?' in Kate Malleson \& Peter H Russell (eds), Appointing Judges in an Age of Judicial Power: Critical Perspectives from Around the World (2006) 39 at 51.

77 Ruddock, above $n 9$ at [62]-[64].

78 Malleson, above $\mathbf{n} 77$ at 48 . We do not consider the process for appointing tribunal members in Australia. There is obviously a case for an independent appointments process for independent merits review tribunals like the AAT.

79 Forge v Australian Securities and Investments Commission (2006) 228 CLR 45.

80 As noted below we do consider the establishment of State and Territory judicial appointment commissions. Whether there will be a national body is itself an issue for consideration. 
activities to identify possible candidates for appointment to the courts within their remit.

- Receive applications for appointment that address the selection criteria.

- Call for references from referees nominated by eligible applicants.

- Call for references from the Commission's nominated referees (a published list of relevant office-holders).

- Assess evidence of qualifications against the selection criteria. Evidence is contained in applications, references, structured interviews and (for some appointments) through formal assessment of applicant's practical skills.

- Recommend three suitably qualified candidates to the Attorney-General for appointment. ${ }^{81}$

We now turn to some specific issues raised by the above points.

\section{A. Scope}

As a matter of principle the model should apply to all jurisdictions in Australia (Federal, State and Territory) and to all levels of the judicial hierarchy in each jurisdiction: commissions should make recommendations in relation to appointments to specialist State courts, the County/District Courts and the State Supreme Courts as well as to all the Federal courts below the High Court. The problems with the current appointments process, as we highlighted earlier, are broadly similar across those jurisdictions and a broadly similar set of responses seem indicated. We will describe later how the model may need to be adapted between Federal, State and Territory jurisdictions to accommodate constitutional imperatives. Some variation may also be required between courts within each jurisdiction: for example, the magistracy in the states and territories has by far the most judicial officers and thus the most frequent need for new appointments and the most possible candidates for appointment on each occasion.

Recommendations for appointments to the High Court should ultimately be made by a Commission. The visibility of the Court means that its inclusion in the model sends a leadership signal about the nature of appointments in Australia. However, we also believe that the Federal Commission should be in operation for a period before any High Court appointments are made through this process. There are a number of significant issues regarding the High Court that need to be carefully considered and accommodated within the Commission framework. For instance, in the case of an unexpected vacancy there is a need for the Commission to move expeditiously. It is not desirable for the Court to have less than its full complement for an extended period of time. Further, the Chief Justice or the most senior Justice willing to serve would be included as a member of the Commission for appointments to the High Court.

81 Where the Attorney-General proposes to make more than one appointment to the same registry of the same court, the judicial appointment commission would provide two more names than the proposed number of appointments. 


\section{B. Selection Criteria}

The Commission should apply selection criteria that track sections 63 and 64 of the Constitution Reform Act 2005 (UK):

1. Selection must be solely on merit.

2. A person must not be selected unless the selecting body is satisfied that he or she is of good character.

3. In performing its functions, the Commission must have regard to the need to encourage diversity in the range of persons available for selection for appointments.

\section{(i) Merit}

An important initial task for each Commission will be to develop the statutory merit criterion into selection criteria that are capable of being put into practice. Its non-legal members should include at least one member with expertise in developing such processes and it should be assisted by an expert secretariat. One recent articulation of the qualities and skills needed for judicial officers was outlined in the The Commissioners' Review of the High Court 2005 Competition. They listed, for example, eight qualities and skills. They were:

1. Analysing and Decision Making

2. Legal Knowledge and Expertise

3. Integrity and Independence

4. Authority

5. Leadership \& Administrative Duties

6. Managing Workload

7. Communicating

8. Treatment of Others. ${ }^{82}$

This example is indicative of an approach that requires the application and assessment process to be made on the basis of known and articulated criteria. The model we suggest will require that the Commission develop a concept of merit in line with best practice in comparable overseas jurisdictions. ${ }^{83}$

Selection criteria should allow candidates to demonstrate that they have the capacity to develop (some) relevant skills within a reasonable time, rather than require them to demonstrate all those skills at the time of application. Some applicants — for example, barristers with a narrowly focussed practice, solicitors, Crown Solicitors, Parliamentary Counsel, Ombudsmen, academics and others -

82 The Commissioners' Review of the High Court 2005 Competition, above $n 45$ at [4.3].

83 While there is broad agreement on the main sub-criteria of the concept of merit, and perhaps these could be spelt out in statute, the concept of merit will need to be spelt out in different ways for different courts and will evolve over time. This flexibility is best achieved by leaving it to the Commission to specify the sub-criteria. It will be accountable for its specifications through their publication in the course of each selection exercise and in its annual reports. 
might already possess most of the skills necessary for appointment and be able to develop the others in an appropriate timeframe. This may be particularly true of candidates with less traditional backgrounds for judicial appointment than those with extensive practice at the Bar. Such candidates should not be excluded from selection on this basis. One consequence of the belief that lack of forensic skill should not automatically disqualify otherwise qualified individuals for judicial office is a need for well-resourced training to accompany appointments. As Chief Justice Gleeson noted when discussing the opening up of appointments to judiciary to non-traditional appointees:

I am not seeking to advocate the retention of the Bar's absolute monopoly on judicial appointment. My point is different; and one that has largely been ignored by people who profess to be interested in breaking down that monopoly. It is that, historically, the monopoly has been protected by the lack of proper arrangements for judicial training and development. Real change, as distinct from windowdressing, in the one area, requires real progress in the other. ${ }^{84}$

\section{(ii) Diversity}

Seeking diversity remains for some the most controversial aspect of the use of an appointments commission. Even those in favour of a commission recognise that there are limits on the extent to which such mechanisms can be called upon to achieve a more diverse judiciary, ${ }^{85}$ at least without addressing the systematic biases in legal education and the legal profession. ${ }^{86}$ On this model, merit remains the sole selection criterion. Diversity in appointments is achieved by recognising that the present undifferentiated merit criterion implicitly limits diversity and by ensuring that candidates previously overlooked are encouraged to apply and be assessed against the articulated components of merit. The focus on merit does not mean that 'colourful' appointments will be excluded by the model. ${ }^{87}$

This model does not endorse the use of quotas or other artificial means to achieve greater diversity. It does, however, recognise the problem associated with a failure to have a judiciary that more closely reflects the society from which it is drawn. Some of the problems associated with under-representation may be traced to the problem of an unarticulated concept of merit. By better expressing what is meant by merit and how it is assessed the Commission will go some of the way to improving at least the means by which greater representation may be achieved.

84 Murray Gleeson, 'Judicial Selection and Training: Two Sides of the One Coin' (Speech delivered at Judicial Conference of Australia, Colloquium - Darwin, 31st May 2003) <http:// www.hcourt.gov.au/speeches/cj/ci_judicialselection.htm> accessed 18 September 2006 (copy at $<$ http://www.webcitation.org/5Xg5Ys727> accessed 9 May 2008).

85 Davies, above n11.

86 See Thomas, above $n 32$ (discussing the need for reform of educational and professional structures in the UK to ensure that there is a diverse pool of candidates qualified for appointment to the judiciary).

87 Compare James Crawford. Australian Courts of Law ( $1^{\text {st }}$ ed, 1982) at 53 quoted in George Winterton, 'Federal Judicial Appointments in Australia' (1987) 16 Melbourne University Law Review 185 at 208. 
The Commission needs to be conscious of the rate of applications from underrepresented groups. The outreach programme will encourage people from diverse backgrounds to apply for judicial office.

Lastly the monitoring and reporting function of the Commission will better inform future appointment rounds and assist in the targeting of under-represented groups.

\section{Outreach and Advertising}

Transparency requires that all suitably qualified members should be made aware of judicial vacancies for which it is proposed to make an appointment. It also reinforces to the public that judicial office is a public office that is selected solely on merit. The Commission will be responsible for outreach into the legal community to encourage individuals to apply. As the United Kingdom Commission challenged potential applicants, 'don't be shy — apply! ${ }^{88}$

A number of outreach techniques may be considered such as advertising positions, writing directly to all practitioners meeting the statutory criteria, ${ }^{89}$ providing detailed application kits with biographical details of typical and atypical recent appointments.

We recommend that the Commission not maintain lists of potential appointees. Such lists might have value if they ensured that the Commission took into account all relevant candidates when a particular vacancy arose.$^{90}$ However, that objective can be achieved by other means without the risks associated with keeping lists of names. On a practical level the maintenance of up-to-date lists is a significant logistical exercise. Without resources these lists may quickly go stale. The collection of names also raises issues of confidentiality. Furthermore, any list would be of limited value as appointments will be made against jurisdictionspecific or court-specific criteria. Thus, lists would not achieve more than a welltargeted outreach programme.

A persistent criticism of the outreach aspect of the model, and of appointments commission processes more generally, is that the effort required to complete the processes will deter good people from applying. This is potentially a serious concern, as empirically indicated until recently in England and Wales. A similar criticism, however, could be made of those that apply for any public office, or application for silk at the bar. We believe that whatever 'damage' the application process may be perceived to do to the judicial office is outweighed by the benefits provided by the reform to the appointment process, particularly if the process can be streamlined so that applicants need not provide significant amounts of material of doubtful relevance and limited utility. The experience in the United Kingdom

88 Malleson, above $\mathrm{n} 76$ at 43.

89 To avoid the irritation of unsolicited letters individuals will be able to opt out from being contacted by the judicial appointments commission.

90 When several appointments are made at the one time or in very short succession, it may be possible to make recommendations based on information gathered during the one selection process, rather than undertaking separate selection exercises. 
has been that after some initial resistance a new culture of judicial appointment is emerging. Moreover, as the process is founded upon merit, applicants will be assured that extraneous considerations will not be taken into account.

\section{Applications}

The Commissioners, with the support of the secretariat, will consider applications for the advertised judicial vacancy. This core function will start with the receipt of the applications and will have a number of distinct phases.

A number of general points should be made about this process. First, applications should be made on a standard form based upon the criteria determined by the Commission. Again the disaggregated and articulated merit principle will shape the contents of the application.

Second, the application form will allow an applicant to demonstrate their capacity to comply with any statutory requirements (such as years of admission) and address the knowledge and skill requirements of the particular vacancy. The application form will provide for a degree of self-assessment on the part of the applicant against the criteria.

Third, the applicant may nominate referees that the Commission will contact as part of the consultation phase.

The secretariat will assess the application forms in this initial stage for completeness and objective qualifications, such as compliance with statutory requirements. The bureaucratic processes associated with the management of applications need to be efficient as well as thorough. Applicants need to be confident in the management of the process. In the United Kingdom some concerns have been raised of the overly bureaucratic nature of the application regime. This is a serious one and needs to be addressed by the Commission.

\section{E. Consultation}

Consultation with interested parties about potential candidates for judicial office has historic and, in the case of the High Court, statutory foundations. ${ }^{91}$ Judges have been consulted in the appointment process, either because they are regarded as the best assessors of the merit of prospective appointees or (particularly in the UK) because their central role is perceived to be an essential guarantor of the apolitical nature of appointments. ${ }^{92}$ Consultation is valuable when it has a clear rationale and scope. That should be to expand the range of prospective candidates and to provide evidence to the selection body about how candidates (and, in the

91 Famously Sir Garfield Barwick was critical of the degree of consultation that Mr Whitlam accorded him when selecting Justice Lionel Murphy. Reportedly Whitlam met with Barwick to discuss possible replacements for the vacancy left by the sudden death of Sir Douglas Menzies. Murphy's name 'was not mentioned'. When Whitlam next contacted Barwick he announced that 'Murphy has agreed to accept the appointment'. Garfield Barwick, A Radical Tory (1995) at $232-33$.

92 The latter point is put forcefully by the UK Judges' Council response to the consultation papers on constitutional reform, available at <www.dca.gov.uk/judicial/pdfs/jcresp.pdf $>$ at [71] (archived $<$ http://web.archive.org/web/*/www.dca.gov.uk/judicial/pdfs/jcresp.pdf $>$ accessed 9 May 2008). 
outreach phase, prospective candidates) meet or fail to meet the selection criteria. ${ }^{93}$ It should be neither ritual nor deferential ${ }^{94}$ and the selection process should rely on evidence disclosed through that process and not on rumour and supposition..$^{95}$

Once the concept of merit is disaggregated into its constituent components, it is clear that judges require a greater range of skills than those traditionally associated with the bar, from which the great majority of judges have been drawn. Moreover, many of those skills, such as industry, a capacity to listen courteously and to understand others, ${ }^{96}$ are themselves generic and can be found in other parts of the profession. It is therefore important to recognise that assessment of candidates for appointment should take into account a wider range of evidence than the views of the senior judiciary on the forensic and other courtroom skills of the barristers who appear before them.

The UK Judicial Appointments Commission was established following consistent complaints about the transparency and accountability of the existing process which "relied to a large extent on secret "soundings" of the senior judiciary' late in the appointment process. ${ }^{97}$ The Commission for Judicial Appointments in England and Wales (the JAC's predecessor) argued that the concerns arising from secret soundings, or reliance on personal knowledge of the applicants more generally, can be addressed by ensuring that such input is supported by detailed examples and is relevant to the needs of the post, and is available in a timely manner to those assessing candidates. ${ }^{98}$ It therefore recommended that the practice of seeking input from the senior judiciary at a late stage in the selection process should cease as:

[i]t reinforces perceptions that judicial appointments are in the gift of the Senior Judiciary and that the system is susceptible to patronage. Judicial intelligence about the extent to which candidates fulfil the relevant criteria/competencies

93 In considering the use to be made of judicial panel members' personal knowledge of candidates, it was recently been stressed by the Commission for Judicial Appointments in the UK that use can be made of such knowledge subject to the all-important caveat that it is "clearly evidence-based': The Commissioners' Review of the High Court 2005 Competition, above $\mathrm{n} 45$ at [8.51]. See also at [8.18]-[8.28].

94 The detrimental effects of a deferential approach to intervention by the senior judiciary is discussed in Commission for Judicial Appointments, The Commissioners' Review of the Recorder 2004/05 Competition (Midland Circuit): Report to the Lord Chancellor (2005) at [3.37].

95 On the need to determine whether rumours adverse to a candidate's selection are substantiated when they first emerge, rather than later in the practitioner's career see id at [3.37] (recommendation 11).

96 Mason, above n20 at 10.

97 Thomas, above $\mathrm{n} 32$ at section 1.3. See also The Commissioners' Review of the High Court 2005 Competition, above $n 45$. For empirical findings attesting to suspicions in the pool of potential judicial applicants relating to the use of secret soundings in the judicial appointment process: see Centre for Research in Equality and Diversity, Assessment Centres for Judicial Appointments and Diversity: Research Report for the Department of Constitutional Affairs (2006) 11 at 58, 62-3.

98 Report of the Commissioners' Review of the Circuit Judge 2005/2006 Competition at [4.23]. 
should be collected earlier in the process and taken into account in a clear and transparent way. 99

Our model maintains consultation but provides for a more structured process by which it is undertaken. In general, consultation brings both strengths and weaknesses to the appointment process. The main strength is that it provides evidence-based assessment of the respective qualities of candidates. The main weaknesses are that there is a real risk of non-evidence-based assessment being entertained and it tends to privilege the more visible candidates to the detriment of diversity and public confidence. ${ }^{100}$ Arguably this is the nature of the current consultation process in Australia. The risks are particularly acute when consultations seek to ascertain the candidate's substantive legal or political views or involve the political branches of government. ${ }^{101}$ In 1913 when Prime Minister Hughes was considering appointing Albert Piddington to a vacancy on the High Court, he asked Piddington's brother-in-law to sound out his views on the relation between Commonwealth and State powers. Having satisfied himself that Piddington was 'in sympathy with supremacy of Commonwealth powers', Hughes appointed him to the High Court. In the face of intense criticism to the effect that Hughes was seeking to stack the High Court, Piddington decided to resign on the grounds that he had compromised himself. ${ }^{102}$

Recent English experience suggests that some forms of consultation do not address the selection criteria of merit. For instance in The Commissioners' Review of the High Court 2005 Competition it was noted that:

One assessor commented that the quality of responses was improving, but it had started from a very low base. Much automatic consultee input was useless. Many more senior judges had done a better job than previously, even though some continued only to offer the odd word. Some consultees offered only comments, but not scores. Some gave only summaries which effectively produced a rank order, but without evidence. There were now both good and bad examples of consultees [sic] responses that could be used to guide future respondents. ${ }^{103}$

The process of consultation needs to be carefully managed. The Commission must ensure that consultations with traditional sources of advice are maintained and

99 The Commissioners' Review of the Recorder Competition 2004/05 Competition (Midland Circuit), above n94 at [3.37] (recommendation 12).

100 These concerns were identified in the UK: see, Commission for Judicial Appointments, Report of the Commissioners' Review of the Circuit Judge 2005/2006 Competition (2006) at [4.17][4.23]. These comments were addressed to observations of senior judicial intervention late in the appointments process.

101 For a recent allegation of inappropriate probing of the political views of candidates for the judiciary see Misha Ketchell, 'Is This How the Australian Government Selects its Top Judges?' (3 July 2006), copy on file with the authors. For an expansion on related points on the potential for political patronage in the current process: see Davies, above n11 at 3-4.

102 Morris Graham, 'Piddington' in Tony Blackshield, Michael Coper and George Williams, The Oxford Companion to the High Court of Australia (2001) at 534.

103 The Commissioners' Review of the High Court 2005 Competition, above $\mathrm{n} 45$ at [6.5]. 
expanded. These 'automatic consultees' need to respond with evidence-based assessments of the candidates or their assessments should be ignored. The automatic consultees should go beyond the traditional sources of advice to ensure that less visible candidates are not excluded from the pool of applications.

The last issue to be considered with regard to consultation is the availability of the consultees' reports to the applicant. There are two competing principles in terms of their disclosure. Obviously transparency and procedural fairness would suggest that adverse assessments should be made known to the applicant, if only for them to know of its existence. Alternatively, the fundamental need for candour and frank assessments of applicants suggests that they should not be disclosed to an applicant. On balance we recommend that reports not be made available to an applicant but that if the Commission proposes to take into account negative comment (supported by evidence) contained in such reports that it disclose the gist of the information to the applicant and afford him or her an opportunity to respond. Given that applicants can nominate referees or consultees and the assessments are to be evidence-based against set criteria, there is a balance and degree of fairness accorded to the applicant.

\section{F. Assessing Candidates}

\section{(i) Shortlisting}

At this stage it will be necessary to sift or shortlist applications to identify the candidates to be interviewed. Because of the numbers of applicants, the shortlisting may need to be carried out by the Commission's secretariat. If so, it should be carried out under procedures developed and monitored by the Commission. The shortlisted candidates should be those whose formal applications are rated most highly when measured against the selection criteria.

\section{(ii) Interviews by Panels of The Commission}

Shortlisted candidates should be interviewed by panels composed of Commission members. A panel system is considered the most appropriate given that the full Commission is too large and unwieldy, and its members too busy, to carry out all the interviews. Each panel should consist of one judicial member, one legal member and two non-legal members, with one of the non-legal members presiding.

Where there are large numbers of applicants or candidates, it may be difficult to assess their suitability for the particular position in the absence of an interview. Through the interview process 'the interviewing panel... [can] become acquainted with applicants and ... assess their qualities against appropriate criteria' ${ }^{104}$

Interviews must be structured and targeted to assessing the candidate's claims against the selection criteria. There should be no room for discussion of the candidate's substantive legal or political views. Subject to these overriding

104 Sackville, above $\mathrm{n} 15$ at 142 . See to the same effect the recommendations of The Commissioners' Review of the High Court 2005 Competition, above $\mathrm{n} 45$ at [8.49]. 
principles, the Commission should develop and publish protocols for interviews that are in line with international best practice.

A formal interview process is an important element in assessing the candidate's claims against the selection criteria. '[E]ven in the case of candidates known by repute, [a formal interviewing process might well reveal] aspects of their character or qualities that might not generally be appreciated. 105

Systematising the interview process, and divorcing it from the political branches of government, helps counter the idea some candidates are favoured or appointed because of the content of their private interview with Attorney-General.

\section{(iii) Assessment of Skills - Assessment Centres}

The skills associated with judicial office travel beyond the mastery of the law. One means by which these skills can be assessed is through practical exercises designed to test legal skills in realistic but hypothetical situations. In the United Kingdom assessment centres are used to test the ability of applicants to deal with a range of situations such as difficult litigants or sensitive situations. These assessment centres may provide a useful tool in the selection process, since Australia, unlike the United Kingdom, has not had the widespread practice of appointing part-time judges, a practice that provides both a training ground and a career path for potential appointments.

We recommend the use of assessment centres as a method of assessing candidates. In particular where appointments are being considered for local or magistrates courts, a practical demonstration of skill may assist the selection committee. The same argument can be made for higher courts. What will dictate the use of assessment centres is a view by the Commission as to the best means of assessing applicants against the stated criteria. This may vary depending on the nature of the jurisdiction.

\section{(iv) Final Assessment by the Whole Commission Rather Than a Subset}

In England, selections for some courts are made by panels drawn from the Commission rather than by the whole Commission and more generally the Commission can delegate the power to make selections to subpanels. ${ }^{106}$ We do not recommend this approach in Australia. The Australian Commissions will be making considerably fewer appointments than the English Commission. The practical issues involved in convening the whole Commission are therefore much attenuated. There is also a benefit to having the perspectives of each of the members of the Commission involved in the selection process, particularly if different Commissioners have been involved in different interview panels. Each has something to contribute.

105 Sackville, above $\mathrm{n} 15$ at 142 .

106 See, for example, Constitutional Reform Act 2005 (UK) c 4, ss 79-80. 


\section{G. Recommending Names}

Once the Commission has assessed prospective candidates against the criteria for the particular appointment, it should provide a shortlist of candidates to the Attorney-General of the jurisdiction concerned. We recommend that this list contain three names. It should not contain just one name. This is a departure from the English model. There are two reasons. First, there will rarely be a uniquely 'best qualified' person. Secondly, judicial appointments have a 'political', in the sense discussed above, component that the Commission is not qualified to assess.

The process that we recommend is:

- The Attorney-General must either recommend that the Governor or Governor-General appoint one of the three candidates recommended by the Commission or require the Commission to reconsider its recommendation.

- If the Attorney-General requires the Commission to reconsider its recommendation, then he or she must recommend to the Governor or Governor-General that they appoint one of the three candidates subsequently recommended by the Commission or one of the three candidates recommended at the first stage. (The Commission may recommend the same candidates.)

- The Attorney-General may only require the Commission to reconsider its recommendations once. If he or she does so, then written reasons must be provided to the Commission for his or her opinion that there is not enough evidence that the person is suitable for appointment.

Clearly this proposal operates as a constraint on the ability of government to reject candidates on political grounds. It may be argued that the constraints on the Attorney-General elevate the Commission to an appointment body rather than one that merely recommends a list of suitably qualified candidates. ${ }^{107}$ In truth it would be difficult, though not impossible, for an Attorney-General to resist the recommendations of the Commission. An alternative has been suggested that would allow greater scope for the Attorney-General to disregard the shortlist where 'legitimate reasons' such as 'the need to add a judge with particular expertise to a court or to take advantage of a "window of opportunity" to appoint a candidate whom the commission did not know was available for appointment when it prepared its recommended short list' ${ }^{108}$ In addition there may be a need 'for geographic balance in a particular court'. ${ }^{109}$

While these are legitimate reasons (and some of which the Commission could choose to incorporate into the selection process) there is a real danger that in relaxing the obligations on the Attorney-General, he or she may seek to sideline the Commission and ignore its recommendations. This could potentially be

107 Ronald Sackville, 'The Judicial Appointments Process in Australia: Towards Independence and Accountability', (Paper given at the Australian Bar Association Judicial Appointments Forum, 27 October 2006 ) at $16-20$.

108 Id at 21.

109 Ibid. 
debilitating for the Commission especially if it was to occur in its infancy. Moreover, the line between 'legitimate' and 'illegitimate' reasons rests upon the Attorney-General making an assessment of the political cost in choosing the latter. Historically this has not proved to be a strong accountability measure.

Our model strikes an appropriate balance between the various principles outlined above. In particular it acknowledges the traditional accountability process of the Attorney-General as well as producing a shortlist of qualified individuals assessed and selected on merit. ${ }^{110}$

The Constitution may be thought to present obstacles to this process applying to Federal judicial appointments. We do not agree. Our proposed model is consistent with the explicit constitutional requirement that appointments of Federal judges be made by the Governor-General. ${ }^{111}$ Appointments of Federal judges will continue to be made by the Governor-General on the advice of his or her Ministers. It has been suggested that there is a further constitutional requirement implied by, but not expressed in, the text of the Constitution. The suggested implication is that the Federal executive government not be constrained by legislation in its exercise of the power to recommend to the Governor-General who should be appointed. In our view, the suggested implication is implausible. As a matter of principle, all executive power is subject to legislative control (unless the Constitution is clearly to the contrary). That is the consistent pattern of several centuries of legal development during which executive power has been progressively brought under the control of the democratic branches of government. It is always a matter for the legislature whether to bring executive power under legislative control or to leave power in the hands of the executive, subject to political control through parliamentary mechanisms. Other commentators who have considered this question agree. ${ }^{112}$

\section{H. Composition of the Commission}

The model outlined in this article has described a generic Australian judicial appointments commission. While a single national appointments body might enjoy efficiencies of scale, there are practical and political obstacles to such an approach. ${ }^{113}$ It is likely that there will be Commonwealth as well as State and Territory commissions ${ }^{114}$ with slight variations between them. For instance some States may wish to graft the appointments function onto existing bodies, such as the Judicial Commission of New South Wales. Further, as with many innovations within the Australian legal system, one State or the Commonwealth may wish to take the lead in establishing an appointments commission.

110 We do not recommend that the Attorney-General be permitted to appoint a candidate not recommended by the Commission: of Williams and Davis, above $\mathrm{n} 75$ at 858-59.

111 Commonwealth Constitution s 72.

112 Tony Blackshield and George Williams, Australian Constitutional Law and Theory ( $^{\text {rd }} \mathrm{ed}$, 2002) at 520; George Winterton, Parliament, the Executive and the Governor-General: A Constitutional Analysis (1983) at 95; Leslie Zines, The High Court and the Constitution $\left(4^{\text {th }} \mathrm{ed}\right.$, 1997) at 262-63. 
Each State or Territory Commission would be a multi-member body of judicial, professional and 'lay' members comprising:

- The Chief Justice of the State, the Chief Judge of the County or District Court, and the Chief Magistrate or Chief Judge of the Local Court (in each case, if the head of jurisdiction is not willing to serve, then the next most senior member of each court willing to serve would become a member of the Commission)

- The President of the State or Territory Bar Association or his or her nominee

- The President of the State or Territory solicitors' association or his or her nominee

- A suitably qualified legal academic chosen by other members of the commission $^{115}$

- Six other suitable non-lawyers qualified by experience and chosen by the other members of the Commission.

The federal commission would be a multi-member body corresponding with the State and Territory Commissions. It would comprise:

- The Chief Justice of the Federal Court, the Chief Judge of the Family Court, the Chief Federal Magistrate or the next most senior member of each court willing to serve

- The President of the Australian Bar Association or his or her nominee

- The President of the Law Council of Australia or his or her nominee

- A suitably qualified legal academic chosen by other members of the commission

- Six other suitable non-lawyers qualified by experience chosen by the other members of the Commission.

The first function of the Commissions is to ensure that judicial appointments in Australia continue to be based on merit. Accordingly, half of the members of each

113 A national body could consist of the members of the State, Territory and Commonwealth Commissions. The constituent bodies would continue to be responsible for recommending appointments in their respective jurisdictions. The national body would be too large and too disparate to function effectively as an appointing body. (Of course, it is consistent with the abstract principles of federalism for a national body to appoint state judges: see, for example, the Canadian system. And in principle a small and workable national Commission could be established to make State appointments. However, this would be a substantial departure from the Australian federal judicial model and would not be consistent with the Australian federal system, whatever its attractions in (say) Canada might be.) The national body on our model would therefore be a body with no formal functions other than supervision of the shared secretariat (through an executive council), and monitoring and policy development at a national level.

114 Perhaps sharing a national secretariat: see part I below.

115 We outline the process of choosing these academic and lay members below. 
Commission must be legally qualified. These members, including three senior judges, have direct experience of those aspects of merit related to legal expertise.

The Commissions are also intended to ensure three subsidiary implications of the particularised and disaggregated merit principle.

- First, judicial appointments must not be made on the basis of the appointee's connections (or perceived connections) to government. Even if members were not captured by government, there would be a risk of that perception arising. It would be pointless — perhaps positively harmful if the politics of appointments were simply displaced into the appointment of the Commission.

- Secondly, judicial appointments must not be made on the basis of the gender, racial, professional and social similarity between appointees and current judges. The risk of appointment on this basis - known in the literature as 'homosocial reproduction' - has been demonstrated in many contexts involving appointment to high level positions, particularly where the selection criteria have not been particularised and disaggregated. ${ }^{116}$

- Thirdly, judicial appointments must be made on the basis of evidence demonstrating those particulars and each Commission must be constituted in a way that is appropriate for assessing that evidence.

These three implications of the merit principle have consequences for the structure and method of appointment of the various Commonwealth and State and Territory commissions.

To the greatest extent possible, members of the Commissions should be appointed ex officio rather than by the government. On our model, six of the twelve members are appointed ex officio. ${ }^{117}$ Although such appointments may appear to represent their organisation on the Commission, the alternatives - appointment by government or appointment by judicial members of the Commission - would compromise the appearance of independence from government or from the judicial members of the Commission.

In our view it is not practicable to have all the members of the commissions appointed ex officio. For example, the Auditor General, Public Service Commissioner and Ombudsman in each jurisdiction would have skills and attributes that are useful in appointing judges. However, their existing workloads would seem to make it quite impossible to have them as active members of appointment commissions.

Neither is the United Kingdom model of having a double layer of appointments practicable. Under such a model, the members of the first small panel are appointed ex officio. They in turn appoint the members of the JAC based on nominations from the Judges' Council, consultations with the professional bodies

116 For a brief survey of the literature, see Ryan A Smith, 'Race, Gender, And Authority in the Workplace: Theory And Research' (2002) 28 Annual Review of Sociology 509 at 521-22.

117 With some modification in the case of federal judicial officers to ensure that the appointment is consistent with the persona designata principle. 
and competitive selection of the lay members. In principle such a system would be desirable but is likely to prove unworkable especially in Australia's smaller jurisdictions.

Judges should not constitute a majority of the members of the Australian Commissions. Although judges must be members of Commissions (because of their expertise in assessing some of the professional components of merit), the risks of homosocial reproduction - in effect capture of the appointments process by the judges - are too great for them to constitute a majority.

For the same reason, the Chair of each appointments commission should be a non-legal member. He or she should be chosen by the judicial and professional members of that Commission after consulting the Attorney-General. He or she is likely to have substantial direct experience of senior appointments processes, for example in industry or the public sector. The remaining non-legal members and the academic member should be selected by the Chair and the judicial and professional members of the Commission. ${ }^{118}$ Once again, the United Kingdom model of a separate appointing panel, although extremely attractive in avoiding the appearance of judges and lawyers having control of the appointments process, would likely be unworkable at least until wider reforms are made to public appointments processes in Australia. The risk of capture should instead be managed by stipulating the criteria for selection of the non-legal and academic members and ensuring public accountability for their selection. Non-legal members should be chosen on the basis of their capacity to contribute expertise to the selection process that is not possessed by legal professionals and judges. The criteria for appointment of these non-legal members should be spelt out in statute highlighting the experience and skills desirable in members. These may include experience in high level selection processes as well as public or private sector management experience. They should not include representation of any particular group or interest. It is desirable that the Commission achieve gender balance as a whole. $^{119}$

A senior legal academic should be a member because of their skills and expertise. In particular, they are likely to have a long term view of developments in Australian and comparative law and judging; to have an understanding of trends in legal scholarship and legal education; to have a grounded view on what constitutes good legal writing; to understand methods for assessing legal knowledge; and to have experience of appointments processes.

Commissions should not include politicians. While political accountability for the appointment of judges is important, that is not best achieved by having representatives of government and opposition on the appointments commission. Although this would ensure a measure of accountability, ${ }^{120}$ it would increase the

118 Once the Chair of the Commission (one of the lay members) is appointed, he or she should be a member of the panel appointing the other lay members and the legal academic.

119 If a jurisdiction adopted an independent evidence-based process for appointment to statutory offices and government bodies, appointments to the Commission in that jurisdiction should be brought within that framework, rather than remain the responsibility of the Commission itself.

120 Allan, above $\mathrm{n} 37$ at $114-15$; and generally Morton, above n41. 
risk of the process leaking and would likely lead to a politicisation of the appointments process and a greater likelihood of 'compromise' selections. Agreement based on compromise between the political parties in selection of judicial officers would only further institutionalise the politics of appointment.

It would be a significant criticism of the overall composition of the Commission if it were too heavily slanted in favour of the legal community and 'the Commission [was] still ... an "insider club". ${ }^{121}$ We agree that the proposal should 'protect against any in-built biases that may exist within the judiciary and profession'. ${ }^{122}$ For that reason, our model moves away from a legally dominated Commission to one in which legally qualified members constitute only one-half of the Commission.

The legal academic and the lay members of Commissions would be appointed for five year terms with the possibility of renewal for a further five year term. However, the first six lay members would be appointed in pairs for three, four and five year terms to stagger the ends of their terms so that their experience is not lost simultaneously.

\section{Secretariat}

Even in the smallest Australian jurisdictions, the appointments commissions will require the support of a secretariat. Although Australia is three times smaller and has fewer tribunals than the United Kingdom, whose Judicial Appointments Commission has a 105 -member secretariat, nevertheless, the total resource demands of the proposed system should not be underestimated. As noted above, there are good federalist reasons for allowing the Commonwealth and the States and Territories to proceed independently of each other. That said, it would be possible for the Commonwealth or the States and Territories to share secretariat facilities while maintaining their own Commissions. That would give it a critical mass that enabled efficient resourcing and a sufficient volume of work to justify a standing body. Without such centralisation, there is a risk of inefficiency due to small size and only occasional work. Absent a national secretariat, the secretariat in small jurisdictions may be absorbed back into the Attorney-General's Department or the Supreme Court, losing the independence that the system is designed to foster.

\section{J. Audit and Accountability}

To enhance accountability, the Commission itself must be subject to appropriate accountability mechanisms.

- It should publish the sub-criteria into which it disaggregates the merit criterion.

121 Nicola Roxon, 'Comment on Proposal for Judicial Appointments Commission' paper given at the Judicial Conference of Australia, Colloquium 2006 Canberra, 8 October 2006 at $<\mathrm{http} / /$ www.jca.asn.au/content/attachments/2006-williams_evans_comments.pdf $>$ accessed 4 April 2007 (copy at <http://www.webcitation.org/5NrSWASKx> accessed 9 May 2008).

122 Ibid. 
- It should provide to the Parliament an annual report and a report on each appointment round. These reports should contain an evaluation of the Commission's outreach activities and of the operation of the selection process.

- It should establish complaints handling procedures. The English experience with the Commission for Judicial Appointments has shown the value of such complaints mechanisms in improving the operation of the overall appointments process.

- Applicants should also be able to lodge complaints with the Ombudsman or the Judicial Services Commission or Judicial Conduct Commission. Thought needs to be given about whether the Ombudsman should have unfettered access to the Commission's files or whether the interests of confidentiality require some restriction on access. The presumption should be against any such restriction.

- The Freedom of Information regime applying to the Commission (and parallel provisions restricting parliamentary access to documents) will need to be carefully designed to protect the confidentiality of applications, references, interviews and assessments, as well of the Commission's deliberations, while allowing for effective scrutiny of the Commission's processes.

\section{Conclusions}

Reform of the process of judicial appointment in Australia is overdue. The current system of appointment is neither rigorous nor transparent; nor does it secure any meaningful accountability of the Executive for its choices.

The model proposed here, like the current system, starts with merit as the sole criterion for appoint to judicial office. However, unlike the current system we wish to replace the unarticulated and untested assertion that all appointments are meritorious with a process that assures the public and the appointee that the judiciary is composed of individuals who have the skills and judgment required to fulfil the responsibilities of judicial office.

Our model draws upon the relevant international experience and adapts it to Australian circumstances. Since the election of the Rudd Government in November 2007, there are indications that the new Attorney-General will be considering reform in relations to Commonwealth judicial appointments. ${ }^{123}$ In proposing a specific model in this article we wish to move the debate beyond the theoretical into consideration of the concrete measures that we believe will ensure that appointments to Australia's judiciary are of the highest calibre.

123 Robert McClelland, 'Judicial Appointments', (Speech delivered at the Judicial Appointments Forum, Bar Association of Queensland Annual Conference, Gold Coast, 17 February 2008) $<$ http:/Www.attorneygeneral.gov.au/www/ministers/robertme.nsf/Page/ Speeches_2008_18February2008-JudicialAppointmentsForum $>$ accessed 4 May 2008 (copy at $<$ http://www.webcitation.org/5XYnHgO8c $>$ accessed 9 May 2008). 


\section{University Library}

\section{- M I N E R VA A gateway to Melbourne's research publications}

Minerva Access is the Institutional Repository of The University of Melbourne

Author/s:

EVANS, S.;WILLIAMS, J.

Title:

Appointing Australian judges: A new model

Date:

2008

Persistent Link:

http://hdl.handle.net/11343/27899 